\title{
Seeking the Seekers
}

\author{
Alec Ryrie* \\ Durham University
}

\begin{abstract}
The Seekers, a supposed sect which flourished in late 1640s England, have generally been neglected by historians, with the exception of Quaker historiography, in which the Seekers play a pivotal but supporting role. This article argues that the Seeker phenomenon is worth attending to in its own right. Perhaps deriving from spiritualist, radical and Dutch Collegiant roots, it also represents the logical outcome of English Baptists and other radicals trying and failing to find ecclesiological certainty, and being driven to the conclusion that no true church exists or (for some Seekers) can exist. The article concludes by examining how the Seeker life was lived, whether as austere, apophatic withdrawal; a veering into libertinism; or by forming provisional communities, communities which did, in some cases, serve as a gateway to Quakerism.
\end{abstract}

The zoo of religious exotica which proliferated across England in the years of the Civil War and Revolution of the 1640s and 1650s has always attracted plenty of attention, but neither evenly nor even-handedly. There has been a good deal written on the phenomenon as a whole: how a Protestant culture which had formerly kept its disputes within relatively narrow bounds suddenly exploded into such exuberant, radical variety, and how the majority who did not join these religious adventures responded. ${ }^{1}$ And there has been much scholarship on individual sects, whether the enduringly significant, such as the Baptists and the Quakers; the evanescent but eyecatching, such as the Ranters and the Fifth Monarchists; or the small-scale but indisputably fascinating, such as the Diggers and the Muggletonians.

* Department of Theology and Religion, Durham University, Abbey House, Palace Green, Durham, DH1 3RS. E-mail: alec.ryrie@durham.ac.uk.

${ }^{1}$ Most recently David Como, Radical Parliamentarians and the English Civil War (Oxford, 2018); see also the indispensable Ann Hughes, Gangraena and the Struggle for the English Revolution (Oxford, 2004). 
Yet one of the supposed sects which was and is regularly listed in the catalogues has largely escaped attention. There is only a modest amount of modern scholarship on the Seekers, and, as we will see, the bulk of it represents a very particular, and problematic, way of framing this movement's history. The only substantial published exceptions to that are an article from $1948,{ }^{2}$ which actually spends most of its length discussing a group the author calls the 'Finders', a label the author admits having invented; and a rather better article from $1984,{ }^{3}$ which gives a proper nod in the Seekers' direction but nevertheless looks mostly at the Ranters, who have a much more developed historiography.

One might conclude from this that the Seekers were an inconsequential curiosity. But this is what Thomas Edwards, the obsessive Presbyterian chronicler of 1640 s sectarianism, had to say about them in 1646:

The Sect of Seekers growes very much, and all sorts of Sectaries turn Seekers; many leave the Congregations of Independents, Anabaptists, and fall to be Seekers.... Whosoever lives but few yeers (if the Sects be suffered to go on) will see that all the other Sects ... will be swallowed up in the Seekers. ... Many are gone already, and multitudes are going that way. ${ }^{4}$

Nor was that simply a momentary panic. Over a decade later, Richard Baxter was asking 'how come so many called Seekers' doubt orthodox Protestant doctrine? His conclusion that Seekers are in fact a catspaw for the Jesuits is paranoia rather than reportage, but he added that it was the 'Seekers ... among whom I have reason to believe the Papists have not the least of their strength in England at this day': he plainly saw them as a significant movement. And indeed he went on to list six different varieties of Seekers he had met, with detailed descriptions and examples of each. ${ }^{5}$

${ }^{2}$ G. A. Johnson, 'From Seeker to Finder: A Study in Seventeenth-Century English Spiritualism before the Quakers', ChH 17 (1948), 299-315.

3 J. F. McGregor, 'Seekers and Ranters', in idem and B. Reay, eds, Radical Religion in the English Revolution (Oxford, 1984), 121-39.

4 Thomas Edwards, The first and second part of Gangraena, or, A catalogue and discovery of many of the errors, heresies, blasphemies and pernicious practices of the sectaries, Wing E227 (London, 1646), 11.

5 Richard Baxter, A key for Catholicks, to open the jugling of the Jesuits, Wing B1295 (London, 1659), 320, 332-4. 
This article's starting-point, then, is simply that the Seekers appear to deserve a little more historical attention than they have received. It will argue that, as well as being a group of interest in their own right, they are an unusually extreme - and therefore unusually revealing case of the relationship between institution and inspiration in the history of Christianity; and also that if we look at the world of radical religion in the English Revolution through their eyes, they give us a different view of radicalism's origins and of its possible trajectories.

\section{WHAT WAS A SEEKER?}

Unlike most of the sectarian labels used in this period, 'seeker' was not an inherently pejorative term. It had a long and rather banal prehistory of being used to refer to Christians striving towards God. So it was simple praise for a tract defending the work of the Westminster Assembly in 1643 to say that 'the whole Assembly are ... Seekers unto God night and day'. ${ }^{6}$ Only in the mid-1640s, not long before the publication of Edwards's Gangraena, did the word become a label for a certain kind, or kinds, of radicalism. That anodyne prehistory is significant, because it meant that the notion of fearlessly seeking after God was already seen in a positive light, and indeed it continued to be used in that way. In 1648 a posthumous collection of sermons by the Congregationalist preacher Jeremiah Burroughs was published under the title Jacobs seed, or the generation of seekers, and it used the word in a wholly positive and traditional sense, in praise of 'the Saints of God that have ever sought God truly' 7 Whether Burroughs's editors were ignoring or playing with the new layer of meaning the word had now acquired, they show that there was still room for ambiguity here, an ambiguity which was open to exploitation. The most famous example of this comes from Oliver Cromwell in October 1646 - just on the terminological cusp - writing to his daughter Bridget Ireton about her younger sister, Elizabeth Claypole:

Your Sister Claypole is (I trust in mercy) exercised with some perplexed thoughts. She sees her own vanity and carnal mind, bewailing it; she seeks after (as I hope also) that which will satisfy. And thus to be a

6 Powers to be resisted, or, A dialogue argving the Parliaments lawfull resistance of the powers now in armes against them, Wing P3111 (London, 1643), 48.

7 Jeremiah Burroughs, Jacobs seed or The generation of seekers, Wing B6090 (Cambridge, 1648), 11. 
seeker is to be of the best sect next to a finder; and such an one shall every faithful humble seeker be at the end. Happy seeker, happy finder! ${ }^{8}$

This passage is cited by every scholar of the Seekers: it was this which set Johnson, in 1948, on the trail of the supposed sect of 'Finders'. Yet it is a very slippery text. It could be taken, perfectly plausibly, to mean that Cromwell was merely talking about simple Christian questing, with 'sect' being no more than a playful metaphor. That is certainly more credible than making him, on the basis of these remarks, into a Seeker fellow-traveller. More likely, however, Cromwell was making use of the space which the word's ambiguity afforded: trying to downplay his daughter's spiritual adventures, and so using the anodyne, generic sense of 'seeker' to smother the new, dangerous sense, which others were even then trying to bring to the fore.

Before we can understand this new sense of the word, a historiographical detour is necessary, for if most scholars have neglected the Seekers, one field has given them sustained and misleading attention. The Seekers have long had a very definite place in Quaker historiography, and most studies of them come from that perspective, including the only monograph dedicated to the subject. ${ }^{9}$ There is a great deal of excellent scholarship in this tradition, and I am indebted to it, but it does also represent a distinctively Quaker tradition. Its bare bones were laid out clearly by William Penn in the 1690s. Penn provided a summary history of Christianity as a repeating process of successive holy withdrawals. So the Protestant reformers broke free from the Babylonian captivity of Rome, but they swiftly grew 'Rigid in their Spirits ... more for a Party then for Piety'. This led separatists, who were 'yet more retired and select', to withdraw in their turn; only to be seduced by power, such that they 'outlived and contradicted their own Principles', leaving some who worried that they

8 The Writings and Speeches of Oliver Cromwell: With an Introduction, Notes and a Sketch of his Life, 1: 1599-1649, ed. Wilbur Cortez Abbot (Oxford, 1988), 416.

9 Douglas Gwyn, Seekers Found: Atonement in Early Quaker Experience (Wallingford, PA, 2000). The most important scholar of the subject, however, was the American Quaker Rufus M. Jones, who returned to the Seekers in several works, in particular Studies in Mystical Religion (London, 1909), 452-67; and Mysticism and Democracy in the English Commonwealth (Cambridge, MA, 1932), 58-104. See also the pioneering work of the nineteenth-century English Quaker Robert Barclay, The Inner Life of the Religious Societies of the Commonwealth (London, 1876). 
were not correctly baptized to withdraw from them once more. These Baptists 'for a time ... seemed like John of Old, a Burning and a Shining Light', and yet all too soon 'worldly Power spoiled them too. ... They grew High, Rough and Self-righteous.' Therefore:

Many left them and all visible Churches and Societies, and Wandred up and down, as Sheep without a Shepherd ... seeking their Beloved but could not find Him, as their Souls desired to know Him. ... These People were called Seekers by some, and the Family of Love by others; because, as they came to the knowledge of one another, they sometimes met together, not formally to Pray or Preach, at appointed times or Places, in their own Wills, as in times past they were accustomed to do; but waited together in Silence, and as any thing rose in any one of their Minds that they thought Savoured of a Divine Spring, so they sometimes Spoke.

Some of these Seekers, lacking humility and 'exalted above Measure', became Ranters and were ensnared in pride and debauchery. But it was when the rest stood firm that God chose

... to Honour and Visit this benighted and bewildred Nation with his Glorious Day-spring from on High; yea with a most sure and certain sound of the Word of Light and Life, through the Testimony of a Chosen Vessel. ... What People had been vainly seeking without, with much Pains and Cost, they by this Ministry found within.

By this he meant that eventually George Fox met them and persuaded them that what they had been seeking was Quakerism. ${ }^{10}$

This is accurate enough to be misleading. It is true that many Seekers did become Quakers, and much of what we know about the Seeker experience comes from Quaker autobiographies. But the Seekers Penn describes are in effect proto-Quakers, anticipating Quaker forms of worship with suspicious precision. It is, as J. F. McGregor recognized, a sign of a deeper problem: for Penn and for most Quaker commentators since, the Seekers do not really signify as a phenomenon in their own right. ${ }^{11}$ Penn tells us nothing about their specific convictions or concerns. They are merely links in

\footnotetext{
10 William Penn, ed., A journal or historical account of the life, travels, sufferings, Christian experiences and labour of love in the work of the ministry, of ... George Fox, Wing F1864 (London, 1694), sigs B2r-C1r.

${ }^{11}$ McGregor, 'Seekers and Ranters', 128-9.
} 
the chain, Quakers who have not yet realized that they are Quakers, supporting actors in someone else's drama. Later Quaker treatments were more sophisticated, but still tended to treat the Seekers as a sectarian version of Schrödinger's cat: mere suspended potentialities, waiting to be resolved by the historian's gaze into either Ranters or Quakers. ${ }^{12}$ From the perspective of Quaker studies, it is still natural to speak of 'the gathered Seeker churches from which the Quaker movement emerged'. ${ }^{13}$ From Seekers' own perspective, as we shall see, the very notion of a gathered Seeker church is somewhere between an irony and an impossibility.

In accounts of Quaker origins, we frequently read narratives of a Quaker preacher who comes upon a meeting of Seekers - or something like Seekers - and convinces them of the Quaker message. If the Quaker movement has a single recognized point of origin, it is George Fox's encounter in 1652 with the group whom Quaker historians have dubbed the Westmorland Seekers: the great Quaker historian William C. Braithwaite described them as 'a people in white raiment, waiting to be gathered'. ${ }^{14}$ If these accounts are read closely, however, a recurrent feature begins to stand out. For example, at Mobberley in Cheshire in 1652, a Quaker preacher visited a group 'whose Custom was when met Together neither To preach nor pray vocally butt to Read the Scriptures \& Discourse of Religion, Expecting a farther Manifestation'. He addressed them, and 'many of them were Convinced'. Again, at Nailsworth, Gloucestershire, in the mid1650s, a Quaker evangelist heard that there had been 'ameeting for some years of apeople called puritants [sic], or Jndependants, a seeking people to know the way of truth'. 'Most of those meeters' came to hear the Quaker, and 'many in and about Naylsworth' were convinced. Or again, in Sussex in May 1655, a Quaker evangelist 'came to a seekers meeting held in Southouer, neere Lewis', and convinced three members of the meeting, which thereafter broke up. Another evangelist in Reigate eighteen months later described how 'a dore was opened for me ... there were seuerall sekers (soe called) and many of them were Convinced'. A further account actually

12 For example, Barclay, Inner Life, 412.

13 Kate Peters, 'Quakers and the Culture of Print in the 1650s', in Laura Lunger Knoppers, ed., The Oxford Handbook of Literature and the English Revolution (Oxford, 2012), 568-90, at 571.

${ }^{14}$ William C. Braithwaite, The Beginnings of Quakerism (London, 1923), 83; cf. Richard J. Hoare, 'The Balby Seekers and Richard Farnworth', Quaker Studies 8 (2004), 194-207. 
written by someone who was 'at a private Meeting ... of those called Seekers' described how when Quakers visited them, he and 'divers also of the same Meeting at the same time' became 'strongly affected' with the new message. A final example: in Bristol in 1654, a group of as many as twenty of those 'which were seeking after the Lord' gathered weekly, spending the day in silent waiting, 'bowed and broken before the Lord, in Humility and Tenderness'. Two Quaker missionaries visited the meeting, and one of meeters was convinced by them, but apparently not many more. ${ }^{15}$ So even these accounts - which are, to be clear, the Quakers' own telling of the story - claim merely that 'many', 'most' or 'divers' members of Seeking groups were convinced by Quaker preaching, or even that only a handful did so. If early Quakers had considerable success recruiting from these groups, they plainly did not convert them wholesale. 'It must not be supposed', Braithwaite warned, 'that the Quaker movement, except in certain districts, absorbed the Seekers en masse. ${ }^{16}$ Quaker historiography has not exactly disregarded that warning: it is has simply shown no interest in those Seekers who rejected their Quaker destiny, other than assuming that they collapsed into Ranterism. From the perspective of the history of Quakerism, that is perhaps fair enough. If we are trying to understand the Seekers themselves, this perspective is seriously distorting.

In Quaker historiography, then, 'Seeker' has become an openly teleological category, a word meaning 'not-yet-Quaker', and used to describe people who may not have had the label Seeker applied to them at the time. Fox's journal itself never uses the word. On a few occasions he described visiting what he called 'Separate' teachers and congregations, which the principal twentieth-century edition of the journal supplements with an editor's note explaining that he meant Seekers. ${ }^{17}$ As we have already seen, some of these nearcontemporary accounts describe these people as Independents or

\footnotetext{
15 Norman Penney, ed., The First Publishers of Truth, 5 vols (London and Philadelphia, PA, 1904), 18-19, 106, 115, 235 (continuously paginated); William Hull, The Rise of Quakerism in Amsterdam, 1655-1665 (Philadelphia, PA, 1938), 122; John Toldervy, The foot out of the snare. Or, A restoration of the inhabitants of Zion into their place, Wing T1767 (London, 1655), 4-7; Charles Marshall, Sion's Travellers Comforted, And the Disobedient Warned (London, 1704), sigs $\mathrm{d} 3 \mathrm{v}-\mathrm{d} 4 \mathrm{r}$.

16 Braithwaite, Beginnings of Quakerism, 27.

17 George Fox, The Journal of George Fox, ed. Norman Penney (New York, 2007; this edn first publ. 1924), 63, cf. 145, 148.
} 
puritans instead of, or as well as, Seekers. Even Penn speaks of people 'called Seekers by some, and the Family of Love by others', an alarming conflation of two rather different radical lineages. For Quakers, therefore, 'Seeker' is a theological category rather than a historical one, a label applied retrospectively to almost any religiously discontented person who eventually becomes or might become a Quaker. Thomas Taylor was an ordained parochial minister before his Quaker convincement in 1652, but he was described as having in those days been 'a Seeking Man, having Real Desires to understand the Things of God ... a true Seeker and Inquirer after the best Things'. ${ }^{18}$ This is no doubt true, but also takes full advantage of the word's ambiguous range of meaning. If we define Seekers in their own terms, it is clear both that by no means all early Quakers started out as Seekers, and that by no means all Seekers became either Quakers or Ranters.

Non-Quaker sources characterize the Seekers rather differently. A heresiographical broadside from 1647 described them as follows:

All Ordinances, Church and Ministry,

The Seeker that hath lost his beaten way,

Denies: for miracles he now doth waite,

Thus glorious truths reveal'd are out of date. ${ }^{19}$

This is terse, but fair. Baxter's sixfold classification a decade later did little more than spell it out. The first, entry-level variety of Seekers, Baxter said, are 'Seekers for the true Church and Ministry; holding that such a Church and Ministry there is, but they are at a loss to know which is it'. The second sort question whether such a church or ministry exists at all; a third openly deny it; a fourth deny the existence of an invisible, universal church as well as of specific churches. The fifth accept that true churches and ministries exist but 'suppose themselves above them: for they think that these are but the Administrations of Christ to men in the passage to a higher state'. The final kind 'think the whole company of believers should now be over-grown the Scripture, Ministry and Ordinances'. ${ }^{20}$ The fifth and perhaps the

\footnotetext{
18 Thomas Taylor, Truth's innocency and simplicity shining through the conversion, Gospelministry, labours, epistles of love, testimonies and warnings ... of ... Thomas Taylor, Wing T591 (London, 1697), sigs B3r, C2r.

19 A catalogue of the severall sects and opinions in England and other nations. With a briefe rehearsall of their false and dangerous tenents, Wing C1411 ([London], 1647).

${ }^{20}$ Baxter, A key for Catholicks, 332-4.
} 
sixth variety stretch the category of Seeker as it was conventionally used: these people appear to have found something, and so are strictly speaking no longer quite Seekers. This, at least, was the view of one such person, the spiritualist preacher John Saltmarsh. Saltmarsh's 1647 book Sparkles of Glory - the title is suggestive of the provisionality so typical of this milieu - was warm about the Seekers, whom he saw as measuring the churches of their own day against the ministry and gifts of the apostolic age and finding them so severely wanting that they could not plausibly be seen as churches in the same sense. Therefore,

... now in this time of the Apostacie of the Churches, they finde no such gifts, and so dare not meddle with any outward Administrations, dare not preach, baptize, or teach, \&c. or have any Church-fellowship. ... They wait ... as the Apostles and Disciples at Jerusalem, till they were endued with power from on high.

Saltmarsh respected this attitude, but believed it was mistaken. To him, such Seekers were backward-looking, expecting the old ministry to be restored: 'a discovery of the Gospel rather as to Christ after the flesh, then $[s i c]$ after the Spirit'. He argued that 'to wait in any such way of Seeking or expectation, is Antichristian'. He particularly disapproved of the Seekers' tendency to subsist in 'secret chambers, or single fellowships' rather than working together and openly for the new era. In other words, his critique was both doctrinal and institutional. ${ }^{21}$ And well it might be, because the central tenet of the Seeker position that he, Baxter and many other witnesses describe is a rejection of institutional churches in any form. There is no church, or at least no church one can be confident deserves the name; and the risk of affirming an erroneous ministry is so intolerable that it is better to remain outside, and better to go thirsty than to risk drinking poison. Revealingly, in some of the earliest texts which use the term Seeker in this sense, the terms Waiter or Expecter are given as synonyms. ${ }^{22}$ The Seekers, in this sense, were

21 John Saltmarsh, Sparkles of Glory, Or, Some Beams of the Morning-Star, Wing S504 (London, 1647), 290-5; cf. idem, The smoke in the temple. Wherein is a designe for peace and reconciliation of believers, Wing $S 498$ (London, 1646), sigs c2r-3r.

22 See, for example, Edwards, The first and second part of Gangraena, 13; 'Wellwisher of Truth \& Peace', A relation of severall heresies ... Discovering the originall ring-leaders, and the time when they began to spread, Wing R807 (London, 1646), 15; Ephraim Pagitt, Heresiography, or, A discription of the hereticks and sectaries of these latter times, $2 \mathrm{nd}$ edn, 
not a sect at all, but an anti-sect: defined by their ironclad commitment to uncertainty.

\section{The Roots of SeEkerism}

We may trace the origins of this paralysing conviction in two ways. The classic method of historians of ideas, intellectual genealogy, is not too different from the heresiographical approach popular at the time. Edwards's Gangraena, which helped to popularize the label 'Seeker' but did not invent it, quite correctly compared the Seekers' principles to those of the self-described 'spiritualist' Sebastian Franck, Luther's contemporary who believed that 'for fourteen hundred years now there has existed no gathered church nor any sacrament'. ${ }^{23}$ There is a spiritualist, radically anti-institutional thread, or rather a series of dots which may or may not be connectable, running from Franck to 1640 s England. ${ }^{24}$ Alongside Franck there is the parallel Schwenckfeldian tradition, which is more openly provisional, denying all current churches but allowing and even expecting that God might act to renew them. There is an isolated but potentially important English precedent in radical circles around the turn of the century, apparently arising from the suspicion that Roman Catholic baptism was invalid, and that true baptism had therefore vanished from the earth and could only be renewed by direct divine initiative. This doctrine, naturally enough, led some individuals to claim to be the new John the Baptist, including the last person to be burned for heresy in England, Edward Wightman in 1612. However, the second-to-last victim of the heresy laws, Bartholomew Legate, who died only weeks before Wightman, took a different tack. Legate,

\footnotetext{
Wing P175 (London, 1645), 141; John Bastwick, The second part of that book call'd Independency not Gods ordinance, Wing B1069 (London, 1645), 37.

23 Thomas Edwards, The third part of Gangraena, Wing E237 (London, 1646), 116; Sebastian Franck, 'A Letter to John Campanus', in George Huntston Williams and Angel M. Mergal, eds, Spiritual and Anabaptist Writers, Library of Christian Classics 25 (London, 1957), 149. This edition of Gangraena includes (at p. 167) a letter from an informant of Edwards's in Lancashire, dated 10 October 1646, which lists 'Seekers' amongst the sectarians troubling the county by that date, implying that by then the term was in use across much of England.

24 This thread is traced in more detail in Alec Ryrie, Unbelievers: An Emotional History of Doubt (Cambridge, MA, 2019), 141-60; but see especially the fuller treatment of it in Jones, Studies in Mystical Religion; idem, Mysticism and Democracy.
} 
according to the second-hand report we have, taught that 'New Baptism there cannot be, till there come new Apostles. New Apostles there cannot be, who are not endued (from aboue) with miracles'. ${ }^{25}$ Yet he did not go on to anoint himself as such an apostle, instead denying all reports of such miracles as 'idle dreams', and so insisting that there is 'no true Baptism in the earth, nor any one true visible Christian'. He supposedly refused to pray with others, on the grounds that Christian fellowship is an impossibility. When a listener begged to join his church, he replied: 'How sillily you speak. I have all this while taught you, that there is no Church. ${ }^{26}$

It is, therefore, unsurprising we can trace no institutional continuity following Legate's execution: how could there have been? There are at least some parallels in the world of underground London radicalism in the 1620s and 1630s that David Como has reconstructed: the antinomianism of that world was distinct from Legate's anti-ecclesiasticism, but they share a common anti-formalist impulse. ${ }^{27}$ Como's antinomians were commonly described as the Family of Love or as Familists, invoking the sixteenth-century mystical Dutch sect of that name: William Penn was not the first to make the connection between the Familists and the Seekers. There does not in fact seem to be any direct link to the original Familists, but other Dutch connections are more plausible and, intriguingly, the Legate family had mercantile connections in the Netherlands. The great vernacular Dutch ethicist of the late sixteenth century, Dirck Volckertsz Coornhert, who was equally ill at ease with Catholicism and with Calvinism, advocated an interim church, which in Schwenkfeldian style he called a stilstandskerk, until a proper apostolic refoundation should come. ${ }^{28}$ In some Remonstrant circles, the idea that there was no true church was taken in radically Erastian directions, as in

\footnotetext{
25 Henoch Clapham, Errour on the right hand, RSTC 5341 (London, 1608), 29-31; cf. the briefer report from John Etherington, A discouery of the errors of the English Anabaptists, RSTC 14520 (London, 1623), 76-7.

26 Clapham, Errour on the right hand, 31-2, 37-8.

27 David Como, Blown by the Spirit: Puritanism and the Emergence of an Antinomian Underground in pre-Civil War England (Stanford, CA, 2004); J. C. Davis, 'Against Formality: One Aspect of the English Revolution', TRHS 6th series 3 (1993), 265-88. 28 Gwyn, Seekers found, 61, 63; Andrew C. Fix, Prophecy and Reason: The Dutch Collegiants in the Early Enlightenment (Princeton, NJ, 1991), 89; Ruben Buys, Sparks of Reason: Vernacular Rationalism in the Low Countries 1550-1670 (Hilversum, 2015); Gerrit Voogt, “'Anyone who can read may be a Preacher”: Sixteenth-Century Roots of the Collegiants', DRChH 85 (2005), 409-24.
} 
the anonymous 1647 tract Grallator Furens, attributed to the minister Pieter Lansbergius, which argued that, since no-one could claim authoritatively to be Christ's representative, anyone might preach, but the state ought not to permit such preachers any status or privileges. ${ }^{29}$ There is something Hobbesian about this strand of thinking: Thomas Hobbes was no Seeker, but his philosophy does depend on a Seeker-like commitment to radical uncertainty.

As Rufus Jones argued, however, the more significant Dutch strand runs through the Collegiant movement, which emerged in the 1620s where the wilder fringes of defeated Arminianism overlapped with the fissiparous world of the Dutch Mennonites. The Collegiants were enthusiasts for Sebastian Franck, and the openness and provisionality of their meetings anticipated Seeker scruples. The most direct connections cluster around the intriguing figure of Adam Boreel. Boreel had family connections across the Channel: his father had been a part of a Dutch embassy to England in 1613, and had been knighted by King James I. At some point in the 1630s, Boreel himself came to study in England. Almost all we know about this visit is that he was 'noted for zeal to Religious ways', and that, according to the hostile witness who is our only substantial source for this episode, he was arrested for being an enthusiast and prophet. After a few months his English friends secured his release, although he was expelled from the country. What mark he may have made during this period we do not know, but it is at least clear that the experience did not sour his view of England as a whole. When the Civil War of the 1640s brought with it a religious revolution, Boreel became deeply involved with a group of prominent English and Scottish thinkers who were trying to put together a bulletproof rationalist defence of Christianity. These friendships, which Boreel regarded sufficiently seriously that he took the trouble to learn the English language, plugged him into an intellectually adventurous milieu which spanned Protestant orthodoxy and emerging

\footnotetext{
29 [Pieter Lansbergius]?, Grallator furens, de novo in scenam productus cum pantomimo suo, Bombomachide ulissingano (Franeker, 1647). For this book's salience to Anglophone readers, see George Gillespie, A treatise of miscellany questions wherein many usefull questions and cases of conscience are discussed and resolved, Wing G761 (Edinburgh, 1649), 1, 7; 'The Correspondence of John Selden (1584-1654)', transcribed by G. J. Toomer, in Cultures of Knowledge Project, Early Modern Letters Online, 193-4, at: <http://emlo. bodleian.ox.ac.uk/blog/wp-content/uploads/2015/01/selden-correspondence.pdf $>$, last accessed 15 January 2021.
} 
radicalisms. His most constant English correspondent, Samuel Hartlib, was a formidable networker, theologian and scientist, who amongst other things collaborated closely with a rising young radical writer named John Milton. ${ }^{30}$

In 1645-6 Boreel would become, in effect, the second founder of the Collegiants. He set up meetings in Middelburg and Amsterdam around which a new movement formed, and published a weird, compelling manifesto. Ad legum, et ad testimonium appeared in Latin in 1645, was never published in Dutch, but did appear in English translation in 1648. By now the outline of his argument will be familiar. Boreel begins from the position that the first apostles' preaching was 'wholly, intrinsically, undoubtedly, and merely true', and that their hearers could be 'infallibly assured of the truth of that word', so much so that even a 'doubting examiner, after a due search, might be infallibly assured that no error ... was to be found there'. He then asks how Christians in his own time might attain that same level of utterly invincible certainty. After many tortuous pages of exhaustive logical sifting, he reaches the obvious conclusion: they cannot. And since no ministers can be fully certain whether they are preaching in accordance with God's will 'or only as it seemeth good to themselves', their ministry is 'tainted'. Any church built on such a foundation is corrupt and therefore intolerable. Such churches have merely split Christendom into a kaleidoscope of factions, and the very fact that none of them have been able to convince the others of their authority shows that they have none. As such, these pseudochurches 'ought to have been very shy of preaching in the name of God' or of claiming divine authority for anything they did. Since they have in fact done the very opposite, he concludes, his readers ought 'to separate themselves from such societies ... accounting them not longer Churches of God, but malignant societies; whereinto the soule of a man fearing God ... ought not to enter'. He has rather less to say about what these scrupulous objectors should do instead.

\footnotetext{
30 Walther Schneider, Adam Boreel. Sein Leben und seine Schriften (Giessen, 1911), 41-2, who bridles at the charge of 'enthusiasm'; Sheffield, University of Sheffield, Hartlib Papers 3/3/32B; cf. ibid. 3/3/60B on Boreel's command of English. On his English links in general, see Rob Iliffe, “'Jesus Nazarenus legislator”: Adam Boreel's Defence of Christianity', in Silvia Berti and Francoise Charles-Daubert, eds, Heterodoxy, Spinozism and Free Thought in Early Eighteenth-Century Europe (Dordrecht and Boston, MA, 1996), 375-96; Ernestine van der Wall, 'The Dutch Hebraist Adam Boreel and the Mishnah Project', Lias 16 (1989), 239-63.
} 
They ought to worship 'privately ... making use of the Scripture as it is', but he struggles to reconcile the plain fact that the Bible requires collective worship with his deduction that no-one can be sure that any form of worship is valid. He concludes tentatively that it may be 'profitable' to join a community which worships tolerantly and 'with an ear always open readily and thankfully to receive better information', in order both to praise God in the unadorned words of Scripture and 'mutually to edify his neighbour in conference'. ${ }^{31}$

The parallels with the English Seekers are unmistakable. Yet actually piecing together the direct connections - if there are any - is not straightforward. By the time Boreel's book was published in English in 1648, English Seekerism was already well established. There may be a link running through the litigious Worcestershire clothier Clement Writer. According to Edwards, Writer dallied with several different heresies before he eventually 'fell to be a Seeker', claiming that 'there is ... no Ministery, nor no Faith, nor can be, unlesse any can shew as immediate a call to the Ministery as the Apostles had, and can do the same Miracles as they did'. Edwards called Writer an 'arch-Heretique'. ${ }^{32}$ He was not, in fact, a Seeker leader there was no such thing, by definition - but he was one of the boldest and most articulate Seeker voices. He laid out his early position most clearly in his 1646 book The jus divinum of presbyterie, a book which is strongly reminiscent of Boreel's 1645 Ad legum, et ad testimonium, both in the way its unusual question-and-answer structure sidles crabwise towards its conclusion, and in the argument itself. Writer's book is not a translation of Boreel but is perhaps an imitation of him. Yet we know of no direct contact between them and we know that Writer did not read Latin. And while the arguments are closely parallel, Writer is less cautious and more far-reaching. He rejects the validity of Christian ministry of any kind, including the validity of water baptism, unless such ministry is authorized by 'mighty works which ... none could do, but by the special power of God'. ${ }^{33}$

\footnotetext{
31 [Adam Boreel], To the lavv, and to the testimonie or, A proposall of certain cases of conscience by way of quaere, Wing T1562 (London, 1648), especially 5, 28, 37-8, 83, 92-3, 96; cf. idem, Ad legem, et ad testimonium (n.pl., 1645).

32 Thomas Edwards, Gangraena, or, A catalogue and discovery of many of the errours, heresies, blasphemies and pernicious practices of the sectaries of this time, Wing E228 (London, 1646), sigs M1r-v.

33 [Clement Writer], The jus divinum of presbyterie, Wing W3724 (London, 1646), especially 12,34 .
} 
There are, therefore, all manner of suggestive hints and halfsubmerged connections which could be woven together into several plausible intellectual genealogies for the Seeker position, but only with the addition of generous amounts of supposition and guesswork. In the 1930s Jones was asking, of the Seekers: 'Did the movement have a founder? If so, who was he? Was it indigenous, or did it originate abroad and migrate to England? If it came from the Continent, when did it originate there and what place was its native habitat?'34 Almost a century later, we have little more in the way of answers than he did, but we are also coming to suspect that this genealogical mode of explanation - which privileges institution above inspiration - can lead us to ask the wrong questions. It is all very well to ask out where ideas come from, but it is perhaps more important to notice that ideas which had been out there in Protestant Europe's meme pool for a century or more suddenly started to flourish as never before in mid-1640s England. Whatever thread may connect the Seekers to earlier generations of radicals, they may be better understood as the most purely distilled example of the spirit of anti-formalism which gripped the conscience of English Protestant culture more widely during the revolutionary decades. ${ }^{35}$ On this view, they were not exotic intrusions but arose from the mainstream. If so, our story is not one of the long descent of a Seeker movement, but the sudden precipitation of a Seeker moment.

Take, for example, what was happening in contemporary New England, a radical Protestant hothouse with its own distinct pressures. It is well known that Roger Williams had, by the mid-1640s, reached a very Seekerish position, to the extent of casting doubt on baptism, although when Cotton Mather describes Williams and his disciples as being of 'that sort of Sect which we term Seekers', he makes it plain that Williams did not use that word himself. ${ }^{36}$ Nor, apparently, did those who (wittingly or unwittingly) followed him. In the summer of 1651, one John Spurr was disciplined by the First Church of Boston 'for his insolent bearing witnes against Baptisme and singing and the church covenant as noe ordinances

\footnotetext{
34 Jones, Mysticism and Democracy, 72.

35 Davis, 'Against Formality'.

36 Cotton Mather, Magnalia Christi Americana: Or, The Ecclesiastical History of NewEngland from its First Planting in the Year 1620. unto the Year of our Lord, 1698, 7 parts (London, 1702), 7: 9; cf. Jones, Mysticism and Democracy, 100-3.
} 
of god'. Eventually, and a little farcically, he was excommunicated 'for his with Drawinge communion from the church at the Lords table'. He had 'professed he could hold noe more communion with the church as it stood', and condemned all of the church's practices, sacraments and ordinances as 'humaine Inventions'. Two more church members were excommunicated on the same grounds later that year, and refused even to come to the church to explain themselves. ${ }^{37}$ The following spring two men in the neighbouring Plymouth Colony were sentenced to a hefty fine or a whipping for 'vild and deriding speaches against Gods word and ordinances', and two years later one of those two was disciplined, along with two others, for withdrawing from public worship: one of the trio 'afeirmed hee knew noe publicke vizable worship now in the world'. ${ }^{38}$ Some at least of them were New Englanders of long standing, not new arrivals from England carrying their sectarian infection with them. The word 'Seeker' was not used, and the churches seem to have been genuinely puzzled by these people's behaviour. And yet there are plainly close parallels between these people and the English Seekers. What are we to make of such parallels? It seems futile to wonder whether or not there were threads of influence, traceable or irrecoverable, linking these New Englanders to Roger Williams, the English Seekers, the Dutch Collegiants or the earlier Spiritualists. The point surely is that whether the seed was imported or home-cultivated, it was finding fertile soil in which to grow. It is quite possible that this was a pristine creation: that the Seekers of Boston and Plymouth were being consumed, not by others' dangerous ideas, but by their own hair-trigger scrupulosity.

For importing intellectual influences was not strictly necessary. To plenty of observers, the Seeker phenomenon did not seem like an alien intrusion, but a logical end point, a reductio ad absurdum, of certain widespread tendencies within the world of Protestant radicalism. In 1645, in one of our very earliest uses of the term 'Seeker' in a sectarian sense, Robert Baillie traced it back to the persistent fear that 'no Church anywhere can have any solid foundation': you cannot be sure it is built on rock rather than shifting sands. This was the root of all separatism, he believed, and drove separatists in the end, 'when they

37 Richard D. Pierce, ed., The Records of the First Church in Boston 1630-1868, 3 vols, Publications of the Colonial Society of Massachusetts 39-41 (Boston, MA, 1961), 1: 52-4. ${ }^{38}$ Nathaniel B. Shurtleff, ed., Records of the Colony of New Plymouth in New England. Court Orders, 3: 1651-1661 (Boston, MA, 1855), 4, 74. 
have run about the whole circle of the Sects, at last to break out into the newest way of the Seekers, and once for all to leap out of all Churches'. ${ }^{39}$ Essentially the same view comes from another very early witness, Edmund Calamy, preaching in January 1646. Very proper Protestant scruples about episcopacy and correct rites of ordination had, he believed, slipped out of control. The Solemn League and Covenant of 1643 had led some worrywarts first to claim that all previously ordained ministers ought to renounce their pretended orders and seek reordination; then to worry that none of the new forms of ordination were sufficiently pure or could be shown from Scripture to be adequate; and thus finally 'to turn Seekers, and to wait till God send Apostles to ordain Ministers'. ${ }^{40}$

Most observers, however, agreed that the root of the problem was not ordination, but a still more fundamental rite of initiation and laying on of hands: baptism. William Bartlet, a minister in Wapping, thought the Seeker phenomenon arose out of a Baptist milieu, with scruples over the correct gospel ordinance of baptism metastasizing into a paralysed inability to be sure any actual baptismal practice was uncorrupt. Baptists themselves were alarmed: the baptistic congregationalist Christopher Blackwood warned in 1646 that 'when you have condemned all ministerie $\&$ baptisme ... you will hardly finde a way to set up any ministery, re-establish any baptisme, but leave us among the seekers, who deny any Church or ministery at all upon earth'. ${ }^{41}$ As early as 1644 , the radical prophet Sarah Jones warned that 'some are seekers out of a Baptism, looking for Elijah, as John the Baptist, to bring it from heaven, forsaking all fellowship till Christ shall send forth new Apostles to lay on hands'. ${ }^{42}$ The word 'seeker' here does not yet have its full sectarian sense, but it is plainly on the way.

\footnotetext{
39 Robert Baillie, A dissuasive from the errours of the time: wherein the tenets of the principall sects, especially of the Independents, are drawn together in one map, Wing B456 (London, 1645), 163.

40 Edmund Calamy, The great danger of covenant-refusing, and covenant-breaking, Wing C254 (London, 1646), 27.

41 William Bartlet, Ba'al-shakoz or, Soveraigne balsome, gently applied in a few weighty considerations, Wing B987 (London, 1649), 4; Christopher Blackwood, Apostolicall baptisme: or, A sober rejoinder, to a treatise written by Mr. Thomas Blake, Wing B3096 (London, 1645 [vere 1646]), 76. On the term 'baptistic congregationalist' for those conventionally described as Particular Baptist, see Matthew Bingham, Orthodox Radicals: Baptist Identity in the English Revolution (Oxford, 2019).

42 S[arah]. J[ones]., To Sions louers, being a golden egge to avoid infection, or, A short step into the doctrine of laying on of hands, Wing J990 (London, 1644), sig. A2v.
} 
Several Seekers recalled having passed with growing scruples and disillusionment through Baptist groups and out the other side. Laurence Claxton, one of the first to be called a Seeker, wrote that most of them were initially 'fallen from the Baptists'. Mary Springett and her husband were initially drawn to the new baptism, but they 'found it not to answer the cry of our hearts'. 'I sufficiently saw', said the one-time Baptist Stephen Crisp, that 'I ... had grasped but at a Shadow, and catched nothing but Wind, and that my Baptism was short of John's. ${ }^{43}$ Luke Howard, a shoemaker's apprentice from Dover, was baptized one February 'when the Ice was in the Water ... with great Joy'. But over the months that followed, observing that neither he nor his brethren were transformed in spirit, he began to worry that it was merely a 'carnal ordinance'. The crux for him came when he was asked to baptize a new convert, and felt he had to refuse. He could not administer baptism to others because 'I was not satisfied in my own'. He told his dismayed fellow-believers that 'I saw myself out (and them also) of the Faith of the Gospel, and that if ever I do come to know it; I shall know it as plain as my Natural Eyes knows that Door. ... And from that time I gave my self up to a seeking state again.' ${ }^{44}$ That sounds painfully principled, and no doubt it was, but as Claxton's chequered career reminds us, there could be more worldly motives. So-called 'dippers', practitioners of adult baptism, were still subject to harassment and persecution in the mid-1640s. Claxton spent six months in prison in Bury St Edmunds in 1645 for baptizing converts. He was eventually released, in part because he was able to swear that his study of the Scripture had now convinced him 'that he ought not to Dip any more'. He pledged to refrain, promising he would 'only wait upon God for a further manifestation of his truth'. The committee understandably did not appreciate that he was renouncing baptism altogether. This far more radical position was, for the moment at least, much less likely to attract legal trouble. ${ }^{45}$

\footnotetext{
43 Laurence Claxton, The lost sheep found: or, the prodigal returned, Wing C4580 (London, 1660), 19; David Booy, ed., Autobiographical Writings by Early Quaker Women (Aldershot, 2004), 82; Stephen Crisp, A memorable account of the Christian experiences, Gospel labours, travels, and sufferings of that ancient servant of Christ, Stephen Crisp, Wing C6921 (London, 1694), 13.

44 Luke Howard, Love and Truth in Plainness Manifested (London, 1704), 8-11.

45 Edwards, Gangraena, or, A catalogue and discovery, sigs K4v-L1r, which triumphantly reveals the implicit deception.
} 
No doubt to begin with some of these people were genuine seekers, in the sense that they were actively searching for something better to replace what they had renounced as inadequate. This is the sense of the word that later Quaker appropriation of the term encouraged. But in fact many Seekers ceased to believe that a true church existed or might exist out there if only they searched for it long and hard enough. If they did search, they deliberately framed the effort in such a way that it could not succeed, measuring it by standards against which the apostles themselves would surely have fallen short. In the meantime, they insisted, as several observers noticed, that 'there is no true Church upon earth'. ${ }^{46}$ That is not a provisional admission of ignorance, but a definitive statement of faith. It was becoming a truism by the end of the 1640s that there was a 'sort of Seekers, who neither seek nor find'. ${ }^{47}$ Mary Springett, passing discontentedly from sect to sect as a young widow, concluded

... that the Lord and his truth was, but that it was made known to none upon the earth. ... There was nothing manifest since the Apostles' days that was true religion, and so would often express that I knew nothing to be so certainly of God, as I could shed my blood in defence of it. ... I ... resolved in my heart I would ... be without a religion until the Lord manifestly taught me one. ${ }^{48}$

That stance has steeliness in it as well as despair. Repeated disillusionment has hardened into a principled conviction that, as this world stands, no church is possible. It is reminiscent of nothing so much as the apostle Thomas's nihilistic blend of faith and doubt, so unwilling to be taken in by comforting lies that he demands to be able to plunge his hands into Christ's wounds; an ultimatum issued to God, in the same deep confidence that he will be able to meet the challenge.

\section{LIVING AS A SEEKER}

Living under such austere principles, Seekers could not avoid becoming exemplars of the dialectic between institution and inspiration

\footnotetext{
46 Richard Allen, An antidote against heresy: or a preservative for Protestants, Wing A1045A (London, 1648), 106-7.

47 The manner of the election of Philip Herbert late Earle of Pembroke, Wing M467 ([London], 1649), 3.

48 Booy, ed., Autobiographical Writings, 82-4, 88.
} 
which this volume considers. Since they believed that they lacked the institution, they found themselves virtually compelled to renounce the inspiration.

It is at this point that the Quaker tradition, with its talk of 'groups' of Seekers loosely defined, and even of 'gathered Seeker churches', becomes positively misleading. The more purist Seeker position renounced collective piety of any kind. In 1645, the Presbyterian minister John Brinsley described that 'the new and strange Generation of seekers' as people who 'stand alone (like a lost sheep in a desert)'. ${ }^{49}$ Robert Baillie described 'the opinion and practice of those whom we call Seekers' as simply that 'they served God single and alone, without the society of any Church'.50 By this account, anti-institutionalism was not so much a consequence of Seeker doctrines as the heart of what it meant to be a Seeker. Much direct testimony confirms the point. Whatever we make of the communities whom George Fox converted, his description of his own life during his early turmoil in Derbyshire in 1647 is compelling:

I fasted much, and walked abroad in solitary places many days ... and went and sate in hollow trees and lonesome places till night came on. ... During all this time I was never joined in profession of religion with any, but gave up myself to the Lord, having forsaken all evil company. ${ }^{51}$

Mary Springett 'gave over all manner of exercises of religion in my family, and in private'. ${ }^{52}$ When John Gratton's conscience drove him out of an Independent church, 'I left them, and all Churches and People, and continued alone, like one that had no Mate or Companion. ... [I] was now afraid to join with any, lest they should not worship God aright.' 53 When Luke Howard left the Baptists behind, 'I mourned in secret with Tears ... in a waste Howling Wilderness, where I could find no Trodden Path, nor no Man to lead me out'. ${ }^{54}$

\footnotetext{
49 John Brinsley, A looking-glasse for good vvomen, held forth by way of counsell and advice, Wing B4717 (London, 1645), 12.

50 Robert Baillie, Anabaptism, the true fountaine of Independency, Wing B452A (London, 1647), 31

51 Fox, Journal, ed. Penney, 7-8.

52 Booy, ed., Autobiographical Writings, 83

53 John Gratton, A Journal of the Life of that Ancient Servant of Christ, John Gratton (London, 1720), 16.

54 Richard Farnworth, The heart opened by Christ, Wing F485 (London, 1654), 12.
} 
What remained of such people's religion? Perhaps prayer and Bible reading alone: but was even that pure, redolent as it was of the hypocritical pious formalities of puritanism? 'When I used all these duties,' a radical named Paul Hobson claimed, 'I had not one jot of God in me.' The seventeen-year-old Edward Burrough tried to steel himself to prayer in 1650 , but heard an inner voice reproving him: 'Thou art ignorant of God, thou knowest not where he is, nor what he is; to what purpose is thy Prayer?' This 'broke me off from praying [and] I left off reading in the Scripture', severing the last moorings still tying him to Christian convention. ${ }^{55}$ Seekers, one sympathizer wrote, 'are entered into their rest, they cease from their labours ... all external forms ... duties of prayer, etc. ${ }^{56}$ Such Seekers were not, could not be, a sect. ${ }^{57}$ They were something more significant: a mood - a diffuse, leaderless, mood which could surface anywhere and which dissolved the bonds which held Christian communities together. Stripping away every remnant of institution, they left no scope for inspiration either. They did not throw out the baby with the bathwater. They deliberately threw out the baby so as to ensure that not so much as a drop of bathwater might be left behind.

This is the farthest point out, at which Seekers had to make a decision: would they really live in this holy vacuum? Those who actually did so are a mystery to us. These people - the truest and most authentic Seekers, if they actually existed - vanish from the record by their very nature. We might question how sustainable such a forbiddingly rarefied apophatic spirituality could truly be, but doubting the existence of such people is in the end an argument from silence, and when we are considering people whose principles committed or

\footnotetext{
55 Edwards, Gangraena, or, A catalogue and discovery, sig. N1v; Edward Burrough, The memorable works of a son of thunder and consolation, Wing B5980 ([London], 1672), sig. E1v.

56 Francis Freeman, Light vanquishing darknesse. Or a vindication of some truths formerly declared, Wing F2129 (London, 1650), 2.

57 Compare the parallel and still controversial argument advanced by J. C. Davis in relation to the supposed Ranters: Fear, Myth and History: The Ranters and the Historians (Cambridge, 1986); idem, 'Fear, Myth and Furore: Reappraising the "Ranters", P\&P 129 (1990), 79-103. Davis had no more patience with 'Seeker' as a category of analysis than with 'Ranter', but his description of the those labelled Ranters as disparate figures whose common antipathy to partisanship led, ironically, to their being formed into a party by hostile contemporaries and by historians also applies, perhaps more convincingly, to the Seekers.
} 
even sentenced them to silence, such an argument is even more dubious than usual. The best we can say is that, since Seekers were human, they may have found it difficult to gaze unblinkingly into the glare of this dazzling darkness. Laurence Claxton's account of his time with communities he called Seekers describes how his former beliefs were peeled away from him like the layers of an onion, until all that was left was appetites, and he was cynically preaching doctrines he no longer believed in order to line his pockets and lure zealous women into his bed. ${ }^{58}$ Claxton's account is deeply problematic, and the dangers of falling for the prurient moral panic that surrounded the so-called Ranters are all too well known. Yet with all the institutional guard-rails of conventional piety removed, it is not hard to believe that some Seekers may have turned their attention to searching for less impossibly transcendent goals.

There was of course an alternative, for those who never went quite so far, or who, having looked over the edge into the void, pulled back. Those have concluded that no existing church, worship or ordinance is valid could be forgiven for wanting to discuss that devastating insight with others of like mind; for wanting to gather regularly to do so; perhaps, even, for doing so at the same hour as their spiritually blind neighbours assembled in their false churches. In July 1645, the Welsh Seeker William Erbury preached forcefully against 'gathering Churches' and baptism, and did so to a gathered congregation numbering some forty people. He compared them to the Israelites in the wilderness, who had manna but not yet the full covenant of circumcision. 'So now we may have many sweet things, conference and Prayer, but not a Ministery and Sacraments. ${ }^{59}$ To be an anti-partisan party is certainly an irony, but it is not necessarily a contradiction. In a tract of 1651 which was one of the most thoughtful and balanced defences of the Seeker position, John Jackson insisted that Seekers did not reject all ordinances. They believed they were called to 'searching the Testimonies of the Holy Writings of Truth', and 'the same touching Prayer, and distributing to the necessity of those that want'. And while these duties were chiefly solitary, there is also some 'coming together into some place on the First-dayes [Sundays], and at other times, as their hearts are drawn forth, and opportunity is offered'. The purpose of these gatherings was to

58 Claxton, Lost sheep found, especially 19-33.

59 Edwards, Gangraena, or, A catalogue and discovery, sig L3v. 
... keep alive, and hold out in their measure their witness and testimony against the false, and waite for the manifestation of the true Lord Jesus, in his pure Ordinances of Mi|nistery and Worship ... expressing their deep sence of the want of what they enjoy not, behaving themselves ... as Sheep unfolded, and as Souldiers unrallied, waiting for a time of gathering, and restitution to the knowledge of what as yet they understand not.

That is certainly deeply austere, but there is at least the ghost of an institution: a body is being kept ready so that inspiration might one day fill it. ${ }^{60}$

This is what we may imagine when we read of Claxton joining 'the society of those people called Seekers, who worshipped God onely by prayer and preaching', ${ }^{61}$ or of John Toldervy attending 'a private Meeting ... of those called Seekers', in which 'two or three ... were making enquiry what should be the meaning of the Spirit of God in two Scriptures, which seemingly did appear to contradict each other'. ${ }^{62}$ We may even believe Charles Marshall's account of how, in 1654 , of

... many which were seeking after the Lord ... a few of us ... kept one day of the Week in Fasting and Prayer; so that when this day came, we met together early in the Morning, not tasting any thing; and sat down sometimes in silence; and as any found a Concern on their Spirits, and Inclination in their Hearts, they kneeled down, and sought the Lord; so that sometimes, before the day ended, there might be Twenty of us might pray, Men and Women, and sometimes Children spake a few words. ${ }^{63}$

Or perhaps we do not entirely believe him. For Marshall, like so many of our retrospective witnesses of the Seeker experience, became a Quaker, and all of those accounts are shaped by hindsight. When he describes something that sounds for all the world like a Quaker meeting avant la lettre, we are entitled to be suspicious.

And yet, for all that we must recognize the relentless undercurrent in this subject's historiography tugging us towards Quakerism; for all

\footnotetext{
${ }^{60}$ John Jackson, $A$ sober word to a serious people: or, A moderate discourse respecting as well the Seekers, (so called) as the present churches, Wing J78A (London, 1651), 3.

61 Claxton, Lost sheep found, 19.

62 Toldervy, The foot out of the snare, 3-4.

63 Marshall, Sion's Travellers Comforted, sig. d3v.
} 
that we must treat the Seeker experience as a phenomenon in its own right, not simply a Quaker warm-up act, there is no escaping the fact that plenty of Seekers did become Quakers, and that Seekerism dissolved into darkness while Quakerism flourished. The takeover was not complete but it was substantial. And it is supremely a story of inspiration and institution: for the Quakers' achievement, in stark contrast to the Seekers, was eventually to develop a structure and a form of collective life and worship which was faithful to the inspiration that drove them, but which also channelled, disciplined and nurtured it. In particular, where Seekers had nothing aside from their own consciences to keep them from sliding into hypocrisy or depravity, the Quakers quickly acquired that rarest and most invaluable of Christian characteristics: a reputation for fiercely authentic morality. It was that which convinced the former Mary Springett, now Mary Penington, that these wandering nobodies whom she had at first dismissed as fanatics were in fact the real thing. ${ }^{64}$ Toldervy, too, was won over by the Quakers' implacable opposition to sin, 'the sincerity of their discourse, with the sobriety of their appearance. ... I concluded, that surely these people were of God, sent forth as witnesses for himself.' 65 When faced with an audience so resolutely sceptical that they denied that a true church was even possible, it turned out that a community who became known for their daunting and unimpeachable moral perfection could make headway.

Even this, however, may have been a symptom of something deeper. The Quakers had, with their doctrine of the light of Christ within, successfully discovered what the Seekers had despaired of finding: a genuinely invincible certainty, a certainty which felt, as Boreel would put it, 'wholly, intrinsically, undoubtedly, and merely true', and of which they could be 'infallibly assured'. Take the case of the former Leveller John Lilburne, in Dover in 1655, where he was visited by Luke Howard, the ex-Baptist and Seeker who had by now turned Quaker. Lilburne asked him, 'I pray, sir, of what Opinion are you?' - a weary question which may be curious for novelty, but does not expect enlightenment. Howard gave an unexpected reply: 'None.' Pressed on the subject, he insisted repeatedly that 'really I am of no Opinion', and he also refused to instruct Lilburne on how to act: 'Thou mayest speak what is in thine owne Minde, \& after thy

64 Booy, ed., Autobiographical Writings, 89.
65 Toldervy, The foot out of the snare, 3. 
owne Manner.' This was the exact opposite of how sectarians usually behaved, and Lilburne was both perplexed and intrigued. Eventually he accompanied Howard to a Quaker meeting. He was unimpressed, feeling that 'his Wisdom was aboue it'. But another Quaker preacher there, George Harrison, told him, 'Friend, thou art too high for Truth', which words, Lilburne claimed, 'gaue him ... "such a Box on ye Eare," that stund him againe'. ${ }^{66} \mathrm{He}$ would go on to live and die a Quaker. In a world of shifting opinions and dubious claims to wisdom, to meet a group who denied holding any opinions, who were confident that everyone who looked inside themselves would find the same truths, and who met only to share in the secret that there are no secrets, was to find unexpectedly what the Seekers had given up seeking. No wonder if, for many of those who had gone out to the farthest point and discovered the hard way that you cannot have inspiration without some form of institution, it was the form of institutionalized inspiration we call Quakerism that offered something they had despaired of ever finding: a home.

66 Penney, ed., First Publishers of Truth, 144-5. 